Marquette University

e-Publications@Marquette

College of Communication Faculty Research and

Publications

Communication, College of

$12-1-1998$

Narrative Analysis of Sexual Etiquette in Teenage Magazines

Ana C. Garner

Marquette University, ana.garner@marquette.edu

Helen M. Sterk

Calvin College

Shawn Adams

Marquette University

Accepted version. Journal of Communication, Vol. 48, No. 4 (December 1998): 59-78. DOI. (C) 1998 Wiley-Blackwell. Used with permission. 


\title{
Narrative Analysis of Sexual Etiquette in Teenage Magazines
}

\author{
Ana Garner, Ph.D. \\ Department of Journalism, Marquette University \\ Milwaukee, WI
}

Helen M. Sterk, Ph.D.

Department of Communication, Arts and Sciences Calvin College Grand Rapids, Michigan

\author{
Shawn Adams, B.A. \\ Department of Communication Studies, Marquette University \\ Milwaukee, WI
}

\begin{abstract}
:
Expanding on existing research on women's magazines, this paper examines the "sexual etiquette" developed in advice columns in magazines popular among teenaged women. Over a span of twenty years, the advice has changed very little. Serving the rhetorical function of field guides and training manuals, teen magazines limit women's sociality and sexuality within narrowly defined heterosexual norms and practices. The rhetoric of sexual etiquette encourages young women to be sex objects and teachers of interpersonal communication rather than lovers, friends, and partners. Young
\end{abstract}


NOT THE PUBLISHED VERSION; this is the author's final, peer-reviewed manuscript. The published version may be accessed by following the link in the citation at the bottom of the page.

women are being taught to subordinate self for others and to be contained once more.

Keywords: teen magazines, narrative, sex education.

Enormously popular and highly successful, women's magazines represent the largest segment of the U.S. consumer magazine industry. Circulations range from 500,000 to more than 1 million. Containing advice on everything from diets and exercise to how to dress and use make-up, and how to attract men, women's magazines play a socializing function through the stories they tell in columns, features, and advertising. Readers encounter and then may imitate cultural myths of identity. Women's magazines particularly fill in the contours and colors of what it means to be a woman and how women should relate to men. According to Kellner, "Media stories provide the symbols, myths, and resources through which we constitute a common culture and through the appropriation of which we insert ourselves into this culture"(1995, p. 5). Magazines constitute part of the media stories that shape both society's sense of culture and our sense of self in culture.

Researchers argue women's magazines play a role in the acculturation of women (cf., Durham, 1996; Ferguson, 1983; May, 1988; McCracken, 1993; McRobbie, 1991; Peirce, 1990, 1993, 1995; Steiner, 1995; Wolf, 1991). Our concern is with the acculturating rhetoric of a segment of this industry; namely, magazines aimed at teenaged girls. The five most popular of these are YM (Young and Modern), 'Teen, Seventeen, Glamour, and Mademoiselle; each with over 1.5 million in circulation (Standard Rate and Data, 1995). Ironically, only a few studies attend specifically to magazines directed at this market (Duffy \& Gotcher, 1996; Duke, 1995; Evans, Rutberg, Sather, \& Turner, 1991; Frazer, 1987; McCracken, 1993; McRobbie, 1991; Peirce, 1990, 1993, 1995; Pool, 1990). Not surprisingly, these studies, like those for their adult counterparts, found that teen magazines work to shape women into enthusiastic consumers who pump money into capitalistic enterprises. Taking it as a given, then, that their latent function is to acculturate readers into consumers, we found ourselves intrigued by the kind of story teen girls' magazines tell

Journal of Communication, Vol. 48, No. 4 (December 1998): pg. 59-78. DOI. This article is (C) Wiley and permission has been granted for this version to appear in e-Publications@Marquette. Wiley does not grant permission for this article to be further copied/distributed or hosted elsewhere without the express permission from Wiley. 
about a narrow, but extremely interesting and crucial part of life, sexuality.

Studies show that teens rank the media just behind peers and parents as sources of information and influence on a variety of attitudes and behaviors, including sexuality (Strasburger, 1995, p. 41). Fine's (1988) study of adolescent females' sexual education found, "public schools have rejected the task of sexual dialogue and critique, or what has been called 'sexuality education'" (p. 30). Peer influence fills in gaps left by schools and parents (Fine, 1988) as does the popular media (Moore \& Rosenthal, 1993; Thompson, 1995). As Thompson (1995) notes in her book Going All the Way: Teenage Girls' Tales of Sex, Romance and Pregnancy, "teenage girls still spend several billion dollars a year and untold hours following the advice of friends and teen magazines to 'fit in but be themselves'" (p. 51). Furthermore, Finders (1997) claims junior high school girls appropriated the experiences reported in teen magazines as their own and the "zines[sic] served as [their] handbook" (pp. 59-60). The girls said "the advertisements and articles were 'just like me'"(p. 61) and "talked as if each [article or ad] carried an implicit command that one must follow in order to achieve high status" (p. 62). They treated the magazine's content as a "ruler" for judging the behavior, values and opinions of themselves and other girls (p. 65). DeFleur and BallRokeach (1982) suggest that people are most dependent upon a given medium when that medium offers the most direct information and when people lack experiences and interpersonal advice required to serve their informational needs.

Clearly, sexual education for teens is not limited to one site or one source. Parents, peers and the media all offer advice. For teenaged girls, it could be argued that magazines are one of the most accessible, inexpensive, and readily available mediums for information about sexuality. Magazines allow for private, repeated readings. They are easily purchased in stores; are free in libraries; and are passed along from friends or relatives. Further, magazines are able to give more explicit kinds of information to readers. As Strasburger (1995) notes print media are more likely than the electronic media to discuss birth control and to advertise birth control products (p. 46).

Journal of Communication, Vol. 48, No. 4 (December 1998): pg. 59-78. DOI. This article is @ Wiley and permission has been granted for this version to appear in e-Publications@Marquette. Wiley does not grant permission for this article to be further copied/distributed or hosted elsewhere without the express permission from Wiley. 
NOT THE PUBLISHED VERSION; this is the author's final, peer-reviewed manuscript. The published version may be accessed by following the link in the citation at the bottom of the page.

In this study, we looked for the story of women's sexuality, both emerging (in magazines directed at younger teens) and maturing (in magazines directed at older teens and those in their early twenties). We asked: what messages do the highly popular teen magazines carry for young women about social and cultural norms for sex and sexual relationships?

\section{Women's Magazines as Training Grounds for Tradition}

Paging through contemporary teen magazines, readers may be struck by the seeming "hipness" of the images. The pictures feature pert, smiling, predominately white, middle-class, young women dressed in the latest fashions. The teenaged models look confident and in control. In short, they imply agency, the ability to do as they choose. However, researchers have found this image to be at odds with the messages carried in the magazines.

The slight body of research available on teenaged girls' magazines suggests they construct a traditional, advertiser influenced, style of female sexuality, one which features pleasing men through enhancing beauty and sexual availability. The 1991 McRobbie study of Jackie, a best-selling British teen magazine, found the magazine scripted for young women a sexually competitive world, in which other girls were positioned as adversaries in the quest for connection with a man. Similar findings marked Evans et al. (1991) study which noted that "articles and advertisements mutually reinforced an underlying value that the road to happiness is attracting males for successful heterosexual life by way of physical beautification" (p. 110). Peirce (1990) also found that traditional socialization messages (such as "finding a man to take care of her") dominated over more feminist messages (such as self-reliance) even when influences from the feminist movement of the late 1960s and 1970s were taken into account. Work by Duffy and Gotcher (1996) argued that YM provided a "rhetorical vision that permeates the magazine lead[ing] the viewer to believe that beauty, costuming, popularity, and romance are the keys to female success" (p. 44). The end result was a "distorted world view ... where success is determined by meeting the needs and expectations of males, and a world view free of consequences for sexual activity" (p. 45).

Journal of Communication, Vol. 48, No. 4 (December 1998): pg. 59-78. DOI. This article is (c) Wiley and permission has been granted for this version to appear in e-Publications@Marquette. Wiley does not grant permission for this article to be further copied/distributed or hosted elsewhere without the express permission from Wiley. 
While these studies addressed issues of sexuality, sexuality was neither their main focus nor purpose. We found no studies focusing specifically on the overt sexual advice given in regular columns. Only one brief, intriguing article, found in the popular press, spoke directly to the nature of sexual advice in teen magazines. The Utne Reader ran a short feature, written by Sassy staff member Elizabeth Larsen (1990), that allowed an inside glimpse into the dynamics of the coverage of sexuality in teen magazines. Sassy's initial editorial policy focused on questions teenaged girls asked them, writing columns and features in response, "to let girls know that whatever choices they made about their sexuality weren't shameful as long as they were responsible about safe sex, birth control, and emotional self-care" ( $p$. 97). Shortly after they began publication, Sassy was boycotted by Women Aglow, an evangelical women's group. Advertising revenue dropped precipitously, until "Sassy had lost nearly every ad account and we were publishing what we jokingly called The Sassy Pamphlet" (p. 97). After reluctantly removing "'controversial content'" (p. 97) Sassy 's advertisers returned. In 1994, Sassy was purchased by Peterson publishers, who also own 'Teen magazine, called "a more traditional and middle-of-the-road publication for teen-age girls" by the New York Times (Carmody, 1994). Anecdotal though it may be, this glimpse inside the workings of a popular teen magazine shows that advice which treats women as relatively autonomous decisionmakers counts as 'controversial.' Significantly, Women's Aglow did not boycott magazines whose columns advised women to act according to more traditional heterosexual norms.

Previous scholarship has revealed that messages about sexuality are present but none have examined the columns that advise young women about issues of sexuality with the explicit intent of understanding the sexual discourse presented in teen magazines. Our purpose is to expand both the focus and range of previous work by examining the explicit sexual advice popular teen magazines have presented to young girls over the past twenty years. We begin by first developing a base founded on Bormann's symbolic convergence theory. 


\section{Symbolic Convergence -- The Merging of Narrative and Culture}

Mediated messages symbolically reflect and shape attitudes and values. Fisher's (1987) paradigm suggests that narratives act symbolically creating meaning for "those who live, create, or interpret them" (p. 58). Narrative, whether persuasive or literary, powerfully packages information, inferences, attitudes and values. Narratives invite audiences to identify themselves with the characters, suggesting motives as reasonable, as working for these characters, encouraging imitation. Symbolic convergence theory, a comprehensive rhetorical theory, originally applied to small group interaction (Bales, 1970) and later elaborated into a theory of public discourse (Bormann, 1972; $1985 a ; 1985 b)$, allows discovery of both long-term social and cultural impact of mediated messages as well as analysis of the narrative elements found within those messages.

Symbolic convergence theory is based upon two major assumptions: first, communication creates reality and; second, individuals' meaning for symbols can converge to create a shared reality for participants. In this perspective, people construct reality through inductive and intuitive forms, such as narrative. It argues that people do not deduce their reality from abstract symbols, rather they create reality based upon interpretation, intuition and shared messages. The power of symbolic convergence theory stems from dynamic narrative, in which people understand events in terms of characters with certain personality traits and motivations, making decisions, taking actions, and causing things to happen. Narrative can shape what people see as possible, even as real, if it is attractive enough and repeated enough.

"Fantasy theme criticism" the method of charting symbolic convergence can be used in media analysis and evaluation. Fantasy refers to the creative or imaginative interpretation of events. Fantasy theme refers to the verbal or nonverbal means through which a particular interpretation of reality appears -- a word, phrase, statement or image. Filling a rhetorical need to explain experience, fantasy themes use words, phrases, statements, or images to interpret events in the past, envision events in the future, or depict current events that are removed in time and/or space from the actual 
activities of the group. Fantasy themes tell a story which accounts for the group's experience and shapes their understanding of what is real.

Just as drama can be analyzed through use of elements of the scene, character, and action, so also can fantasy (Bales, 1970; Bormann, 1972; 1985b). Setting themes depict where the characters act out their roles or where the action takes place. The elements of the scene are closely integrated with characters and action and are given presence through them. Character themes describe the agents or actors in the drama, ascribe qualities to them, assign motives to them, and portray them as having certain characteristics (Bormann, 1985b). Action themes, or plotlines, deal with characters' actions within the drama (Bormann, 1985b). The action of the drama gives meaning to the fantasy theme. Within the drama, motives are personified within actions that converge in a unified vision.

Symbolic convergence encourages group members to be caught up in the drama. Those who share the fantasy act it out (Bales, 1970; Bormann, 1985b). The psychological process of being caught up in the narrative helps group members to interpret some aspects of common experience enabling symbolic convergence on that issue. That convergence creates a coherent rhetorical vision of some aspect of their social reality (Bormann, 1985a). The rhetorical vision is a shared image of what the world is like and how people fit into the world. People who share the vision become a rhetorical community, knit together by a common sense of purpose, agency, motivation, and action.

\section{Method}

We surveyed five magazines aimed at teenaged girls for their advice on sex: $\underline{Y M}$, 'Teen, and Seventeen aimed at a younger (12-19) audience and Glamour and Mademoiselle, whose audience, although older (18-24), includes teenaged readers. Each has been published for at least twenty years and according to Standard Rate and Data (1995) all have circulation's over 1.5 million.

Even though the demographics of Glamour and Mademoiselle indicate an older audience, we include them for three reasons. First, their messages of sexuality continue themes sounded in magazines for

Journal of Communication, Vol. 48, No. 4 (December 1998): pg. 59-78. DOI. This article is (C) Wiley and permission has been granted for this version to appear in e-Publications@Marquette. Wiley does not grant permission for this article to be further copied/distributed or hosted elsewhere without the express permission from Wiley. 
younger women. Given that "by the time they are 20 years old, 70\% of girls and $80 \%$ of boys have engaged in sexual intercourse"(Greenberg, Brown and Buerkel-Rothfuss, 1997, p. 1) these magazines may be sought out for information and guidance. Second, according to Teenage Research Unlimited (1991) Mademoiselle and Glamour captured 14.4 and 18.3 percent respectively of the 12-19 year old market. Mademoiselle reported that $20 \%$ of their readers are between $12-19$ years of age and Glamour reported that $14.5 \%$ of their readers fall within this age group ( $\mathrm{S}$. Martin, personal communication, March 2, 1993). Third, while their targeted audience may be older, younger and mid-range teens find easy access to them in older sister's rooms, libraries, and store shelves.

Focusing on the editorial part of the magazines that gave direct sexual or relationship advice to young women, we analyzed health, sex, and relationship columns, as well as any directly related feature articles or stories from the April and October issues of 1974, 1984, and 1994. We selected these years because we wanted to see if the advice changed over time and reflected the impact of AIDS. We chose advice columns and features because they provide readers the clearest possible picture of what sex and sexual relationships should be like; information supported by the prescriptive advice of the "experts" who author the articles. The 30 issues provided us with 175 articles for analysis. April and October issues were used because we wanted months that would not be influenced by holidays, like Christmas, or special events, like proms and summer vacations.

Relying on categories of analysis drawn from Bormann's symbolic convergence theory, we mapped the narrative of appropriate sexual conduct and expression created by the material as a whole. Within this interpretive frame we looked specifically for sexual metaphors, phrases, and sentences as they relate to setting, character and action. Following the guidelines of Silverman (1993) the three primary authors, as well as two other researchers, read all of the advice columns and stories in all of the magazines and interpreted the material independently making their own lists of sexual metaphors, key words, phrases and sentences. Each recorded their interpretation and whether they thought items related to setting, character, or action. The descriptive lists were collated. As a group, we discussed 
the emerging themes and patterns (major, minor and conflicting ones) and came to agreement on the content and its implications. Differences were resolved by reexamining and discussing the text in question.

\section{The Story of Sex}

In 1974, only 'Teen, Glamour and Mademoiselle directly and openly addressed the issue of sexual activity and sexuality through such topics as sex and the single scene, infidelity, pregnancy and abortion, venereal disease, "his body," and bust exercises. $\underline{Y M}$ and Seventeen spoke more implicitly, focusing on the dating game, dating etiquette, abusive boyfriends, kissing, love letters, going steady, surviving a breakup, and being a loser on the dating scene. By 1984, all more openly addressed male/female sexuality and sexual relations. YM and Seventeen's coverage was not as extensive but it was as definitive. Seventeen, for example, carried articles on teen pregnancy and masturbation, abortion, and sexual double standards. Meanwhile, Mademoiselle and Glamour continued their unabashed approach to sexuality by talking about ejaculations, male attitudes toward their penis, talking too much while lovemaking, and so on. By 1994, the differences in treatment of sexuality among magazines were slim. While Glamour and Mademoiselle talked about erotic dreams with lesbians, satisfying sex with an older man, penis enlargements, last minute flings and so forth; YM, Seventeen and 'Teen discussed wanting babies, boyfriends wanting virgins (and she's not), sex with cousins, sexual abuse, sex between juveniles and adults, chastity belts, whether a guy can tell if you're a virgin, and being addicted to love. In sum, over time we saw a shift in the range and explicitness of topics relating to sexuality. This finding meets Strasburger's observation that contemporary magazines, like television, reflect a trend away from "naive or innocent romantic love" to "increasingly clinical concerns about sexual functioning" (p.46). We did not see, however, any significant change over time or magazine in how women's sexuality was framed. We decided, therefore, to treat the material primarily in a paradigmatic (stressing content-based categories) rather than syntagmatic (stressing change over time) way. Changes over time that we did observe, however, will be discussed.

Journal of Communication, Vol. 48, No. 4 (December 1998): pg. 59-78. DOI. This article is @ Wiley and permission has been granted for this version to appear in e-Publications@Marquette. Wiley does not grant permission for this article to be further copied/distributed or hosted elsewhere without the express permission from Wiley. 
NOT THE PUBLISHED VERSION; this is the author's final, peer-reviewed manuscript. The published version may be accessed by following the link in the citation at the bottom of the page.

\section{Setting Themes}

The setting for the sexual relationship dance between male and female teenagers is rarely named or described in teen magazines. Sex appears to occur whenever and whenever possible. Implicitly, however, teenage sexual activities and relationships take place wherever teens can find a private space at home, parties, or even school. The magazines, however, do not show sexual activity taking place on vacation, at home or within bedrooms -- sites where adults typically engage in sexual activity. This lack of focus on the physical setting is in marked contrast with adult magazines. A cursory review of more adult directed women's magazines, such as Cosmopolitan, Elle and Harper's Bazaar, reveals the importance of place for adults by providing articles that focus on decorating the bedroom or bathroom to make it more romantic or suitable for lovemaking, creating the most "romantic" picnics for two, discovering the most romantic vacation hide-aways, and so on. The question, then, is why is there no clear physical setting for the sexual drama?

The most obvious answer is that parents control the "normal" sex setting. Rules forbidding members of the opposite sex in a daughter or son's bedroom are not uncommon, making sexual activity difficult within the home, especially the bedroom. A less obvious answer is that to focus directly on setting assumes an established knowledge level most, or many, teens do not have. Young teens do not ask sophisticated questions, such as where can I have sex, or what is the most romantic hide-away for sex, but rather, should I have sex, and if I do, "how do I kiss," "give oral sex" or must I have "anal sex if I don't want too?" (Lever \& Schwartz, 1994b, p. 69). The scene of the story then, is not of primary importance. Reducing adolescent uncertainty about the basic nature of sex is.

\section{Character Themes}

Finders (1997) found teen magazines help young women identify the nature of their new adult community, as well as the other actors. In the magazines we surveyed, there are two actors in this sexual drama: the "guy" or boyfriend and the "girl." The most prevalent questions were: What are guys like? What do guys want from girls? How should I behave around guys? Overall, men or "guys"

Journal of Communication, Vol. 48, No. 4 (December 1998): pg. 59-78. DOI. This article is @ Wiley and permission has been granted for this version to appear in e-Publications@Marquette. Wiley does not grant permission for this article to be further copied/distributed or hosted elsewhere without the express permission from Wiley. 
are characterized as users and controllers within the community, while women or "girls" are characterized as negotiators of their own use.

Girls. In teen magazines' girls are assumed to be, quite simply, in the process of "becoming." Girls are never right just as they are. This vision takes on added importance in light of the Gilligan, Lyons, and Hanmer (1987) study which found adolescent girls see themselves as becoming someone in relation to other important persons in their lives, such as their mothers or teachers. Gilligan et al. argue that many girls submerge their individuality and sense of identity in favor of becoming what someone else wants them to be. They found it is the rare girl who maintains her sense of self if it conflicts with what she perceives to be the sense of self promoted by important others. Our analysis finds teen magazines encourage girls to become what significant others, in particular, "guys," want them to be.

Health and relationship advice columns, supplemented and complemented by fictional stories and features on sexual issues, encourage young women to become sexual objects whose lives are not complete unless sexually connected with a man. Girls can earn a man first by recognizing the traditional interests ("affection" and "company") and training of women (to be "ladylike," "neat" and "polite,") (Rubis, 1984) and second, through the changing of self as they negotiate their way through sexual encounters and relationships. Young women achieve the latter by being better informed than guys about male and female physiology and psychology; by attracting guys through good-looking hair, beautiful clothes and thin bodies; and by developing sex and relationship skills. As Seventeen advises: "If you see someone you like or who seems interested in you, let yourself glow. Take a chance. Bring yourself to flirt. Play a little. That's what flirting really is: part of a game between men and women. (What's wrong with games?)" (Wood, 1974, p. 58). According to $\underline{Y M}$, it also helps if they possess the quality of "innocence."

Do you know the one quality boys can't resist? It's innocence. They refer to it by many terms ("cute," "sweet," "adorable," "charming," etc.), but what really attracts boys is innocence. That's why an actress like Brooke Shields is so alluring; she projects childlike, wide-eyed naiveté' into her roles. (Rubis, 1984, p. 47) 
This innocence is especially evident in the 1974 issues of $\underline{Y M}$ and Seventeen where the girls are, implicitly, virgins looking for tips on being a good kisser and proper dating etiquette. "My question is short and sweet: Is it or is it not considered proper to call a boy these days?" (Borchart, 1974, p. 38). Not all of the younger teen are virgins, however, as evidenced by articles in 'Teen on venereal disease ("The Truth Behind VD," 1974) and "his body" ("You, Your Parents," 1974) and in Mademoiselle about "getting laid, " infidelity and abortion (Durbin, 1974a; 1974b; Baudry \& Weiner, 1974). By 1984, girls are told, both subtly and directly, they should focus primarily on understanding the "guy" and meeting, or dealing with, his constant sexual desire and readiness. Even in articles focusing on a young woman's emerging sexuality, such as April 1984's issue of 'Teen, "Sexual Involvement: The Experts Answer Your Questions," young women are warned they can expect to be pressured into sex and experience painful emotional and sexual scars from male/female relationships (Sora, 1984a, pp. 10-12). 'Teen's October issue states:

That's not to say that guys don't value girls as people, but chances are they may have some sexual agenda as well. Girls often get physically involved with a guy to feel close emotionally. Guys are more apt to separate the emotional from the physical. Girls, therefore, can be more vulnerable to getting hurt after getting physical. ("Why Guys Do What They Do,"1994, p. 34)

In order to survive the presumably inherently animalistic traits of men, the October 1974 issue of Seventeen advises girls to be patient as "like most boys, your friend simply doesn't want to make a big display of his emotions, especially in school" (Borchart, 1974, p. 36). In 1984, it advises that when guys "make these lame noncommittal offers, we're also trying to gauge your reaction. If you respond with a friendly smile and a sincere 'that would be great,' we just might come through for once and say exactly what we mean when we make that promised call" (Schwartz, 1984a, p. 104). Glamour cautioned girls in 1984 to avoid the tendency to be "pushy," "bossy," or to act like "mom"( Naifeh \& Smith, 1984). "The other mistake women make is to show their 'independence' by being demanding" (Naifeh \& Smith, 1984, p. 291). In Seventeen and YM, girls must fight the "desperate" urge to get pregnant (Duncan, 1994; Fuller, 1994), 
and in 'Teen they must fight the urge to "pin guys down," or to push for "commitments" before guys are ready ("Why Guys Do What They Do,"1994).

Guys. In teen magazines, guys simply "are." Guys need to know only themselves and, because they "are," they need not worry about "becoming" men or achieving power or status; they already have it. According to'Teen, because they possess these qualities, guys are "allowed to be wild," have "fewer restrictions," and to focus more on "impressing buddies" and "group bonding" than on relationship and communication skills ("Why Guys Do What They Do,"1994, pp. 32-34).

Whether in 1974, 1984, or 1994 guys lack relationship skills and prove unable to express themselves verbally or emotionally. Any presentation of women's sexuality also involves, implicitly or not, a treatment of men's sexuality. Over 20 years men's sexuality, in teen magazines, is narrowly portrayed as animalistic and self-centered; and the sexual advice becomes more explicit and graphic. In 1974, guys are difficult to talk to, use girls, and make them feel like losers, and cheat on them sexually (only in Mademoiselle is this explicitly stated (Durbin, 1974a)). By 1984, guys do all of these things and they are primarily motivated by sex and self-interest. Guys "don't learn [about sex] from talking with the guys. [They] learn from hands-on training with girls" but their training is inherently unsuccessful because they only know the basic mechanics of sex (Nelson, 1984, p. 157). Nonetheless, according to 'Teen, guys push girls beyond their level of sexual readiness (e.g., beyond kissing) or use excuses to pressure girls into sexual intercourse.

Are guys really in pain if they are sexually aroused, then don't have sexual intercourse? . . . It's important to be aware that this "pain" is sometimes used as a tactic to pressure a girl into more sexual activity than she's ready for. For example, if a guy says, "If you loved me, you wouldn't want to see me in pain." This line should be a warning to you that this person puts his own physical satisfaction above your emotional welfare. (Soria,1984a, p. 9-10).

Younger teens are told by Seventeen that guys kiss you and then call you "stupid" (Schwartz, 1984b, p. 68); by 'Teen that guys 
start going "out a lot" and "stop coming around" when you get pregnant (Soria, 1984b, p.91); by $\underline{Y M}$ that guys only marry virgins (Clifford,1994p. 37), and by 'Teen, again, that guys toy with your emotions or "act mean" because they "want to be cool in front of friends" (Nguyen, 1994, p. 30). Older teens are warned by Mademoiselle that guys deceive you sexually and emotionally (Durbin, 1974a); by Glamour that guys demand that you "make [yourself] irresistible to other men" as a means of measuring your worth and his own (Barbasch, 1984, p. 325) and by Mademoiselle, that guys ask you to do things like join in a threesome with your best friend (Vernon, 1994, p. 74).

Ironically, these male ways of being, while depicted as regrettable, are not shown as lacking worth. While the advice columns overtly guide young women to accept men as they are, further guidance comes from other parts of the magazine, in particular, the celebrity biography and photo spread. In teen magazines "guys" are set up as ideals or poster boys meant to be treated by young women as icons: someone to placate, adore and manipulate. This ideal, twodimensional male is presented as the type of "guy" who can fulfill the "girl's" dream, standing in for all men for young women trying to understand and know men's wishes, needs and behaviors. "Warning: 'TV Turn-ons,' our tear-out-and-tape-it-to-your-wall story, may be damaging to your social life. Once you get a look at our favorite guys from the new fall shows, you'll be tempted to stay home every night and glue yourself to the couch in front of the tube" ("TV Turn-Ons," 1994, p. 10). Young women, encouraged to "study" these icons as if they were the enemy, read about "guy" qualities and characteristics in order to survive within the community.

\section{Action Themes}

The narrative clarifies the elements of sexual advice and tells the reader which elements are the most important; it stresses the kind of character, the kind of person, the young woman should strive to be within the community. Three central action themes emerged from our analysis and all presume the sexual activity of young women; suggesting how she should adapt herself to sex, as young men want it. We should be clear, these magazines do encourage women to be selfreliant, to defend themselves and their desires for better treatment 
within a relationship. The women are not told to be patsies nor are they told to let men walk all over them. Independence and emotional strength are touted in all the magazines. These messages, however, are usually not tied to the woman's own sexuality. Instead, the predominant themes include presenting oneself as sexually desirable (not desiring), developing the skills of sexual therapy--designed to enhance men's sexual pleasure and performance, and becoming a communication teacher--in order to help guys become better relational partners.

Woman as Sex Object. As members of the adolescent, sexually active community, young women are told to always be sexually desirable and ready for sexual activity. This is not to say the advice columns, like those in Seventeen and $\underline{Y M}$, do not tell young women to "wait" until they are emotionally (Kent, 1994) or legally "ready" (Clifford, 1994; Lee, 1994). They repeatedly caution young women about engaging in sex before they are ready. However, woven into these cautions is the underlying assumption that readers are, or soon will be, engaging in sexual activity. The presumption is that sexual intercourse will happen before marriage. The only questions are where, when and with whom.

Magazines tell young women to be ready and willing through the standard articles and advertisements on "sexy outfits," "sexy hair he'll love," and "passionate fingernails." They encourage girls to "shape-up" for that "sexy swimsuit he'll love" and to eat right for that "healthy" and "sexy" glow. Through advice columns, like those in Mademoiselle, older teens read questions from other teens regarding whether it is safe to have sex if your boyfriend has cold sores ("he say's not to worry") (Rosenbaum, 1984, p. 50), whether sex is better when your bladder is full (Vernon, 1994, p. 78), or whether getting pregnant to "tie a man down" is ever successful (Baudry \& Wiener, 1974, p. 34). Older teens can also read in Glamour about how to deal with the sexual activities men desire of women. "I've been seeing a guy for a couple of months. Our sex life is great, but lately he's been asking me to perform oral sex on him. I'd love to -- but I don't even know how to begin. Please tell me" (Lever \& Schwartz, 1994a, p. 76). Through discourse such as this, younger women are told that others within their community are actively engaging in sex; and that others achieve success and status within their community through sexual intimacy.

Journal of Communication, Vol. 48, No. 4 (December 1998): pg. 59-78. DOI. This article is (c) Wiley and permission has been granted for this version to appear in e-Publications@Marquette. Wiley does not grant permission for this article to be further copied/distributed or hosted elsewhere without the express permission from Wiley. 
NOT THE PUBLISHED VERSION; this is the author's final, peer-reviewed manuscript. The published version may be accessed by following the link in the citation at the bottom of the page.

This sense of a sexually active community is especially evident in the 1994 magazines geared toward the younger teens. Here, young girls write to YM about having sex with their 18 year old boyfriends when they are 14 years old (Lee, 1994), or to 'Teen about sex when they are 13 years old ("Ask Juli," 1994b) or to Seventeen about their desire to have a baby (Duncan, 1994). In YM one girl wrote: "I'm a 15-year-old girl and I want a baby-- in fact, I've always wanted a baby. I've been going out with the guy for about seven months. . . . I've agreed to wait, but it hurts really badly -- I want a child so much" (Fuller, 1994). In 1984, the sexual activity of the younger women was more implicitly addressed in these same magazines through articles on sexual involvement (Soria, 1984a), pregnancy (Kellogg, 1984; Graeber, 1984), and premature parenthood (Soria, 1984b). In 1974, only 'Teen magazine acknowledged sexual activity beyond kissing through its discussion of venereal disease ("The Truth Behind VD"). This shift, over time, in content acknowledging sexual activity seemingly corresponds with increased teen sexual activity noted by Greenberg et al. and the editorial trend cited by Strasburger. Regardless, what these articles and columns for younger and older teens rarely address are the teen's own sexual needs and concerns. The one exception was the "Sex and Your Body" column in Seventeen (McCoy, 1984) entitled "Masturbation: normal or not." Even more importantly in the age of AIDS, young girls are rarely told how to protect themselves.

Over time, in the advice columns to younger teens, young women who are not ready for sex, or are having problems getting dates, are encouraged to employ self-analysis for possible emotional or behavioral problems (e.g., is she "not getting enough love from [her] own parents" (Fuller, 1994, p. 28), or is she "too dependent on him?" ["Whoa!" 1994, p. 46]). Young women are advised to let their "shyness" work for them and stop being "flirts [and] social butterflies" because "boys like to feel special. They love it when you shower them with [selective] attention" (Rubis, 1984, p. 47). According to Seventeen if you are a "loser" because you "can't bring [yourself] to flirt the way some girls do because it seems so fake" you should examine your own anger and hidden feelings and reconsider "the other old saw: A boy runs after a girl until she catches him!" (Wood, 1974, p. 58).

Journal of Communication, Vol. 48, No. 4 (December 1998): pg. 59-78. DOI. This article is @ Wiley and permission has been granted for this version to appear in e-Publications@Marquette. Wiley does not grant permission for this article to be further copied/distributed or hosted elsewhere without the express permission from Wiley. 
Self-analysis is also a way young women can determine what may be going "wrong" in a relationship. The "Dear Jill" column in 'Teen (October 1984) suggested:

Next, it may help to examine how you're acting around guys, to make sure you're not sending out the wrong signals. For example, do you act naturally around guys? Some girls get caught up in acting according to how they think a "popular" girl would act, rather than how they feel most comfortable. This often appears phony. Are you too complementary? Sincere compliments seem insincere when they're dished out excessively. Do you tend to talk too much around guys? (p. 24)

Are they "ask[ing] him questions about himself" or are they filling "the dead space with tales about [her]self" or are they "cornering him into a commitment" ("Dating Dilemmas,"1994, p. 18)? Questions such as these encourage several assumptions on the part of young women: a) relationship problems are women's fault and their responsibility; b) women must subjugate self for the sake of the relationship; and c) women who do not make men the center of the relationship will not succeed as members of the community. This self-analysis, and the self-help culture which promotes the continued social and emotional subordination of women, has been well studied (cf. May, 1988; Tavris, 1992; Simonds, 1992), but the sites of study have been adult women's magazines and self-help books. These cultural messages begin much earlier.

Because guys are "inconsiderate," "manipulative," and "possessive" girls can expect to be treated like "dirt." Teen magazines provided explanations as well as potential solutions or warnings for this "guy" behavior. According to 'Teen, for example, "guys" act "kind of mean because they want to act cool in front of their friends." The solution is to "be nice to him-- suggest swapping phone numbers" (Nguyen, 1994, p. 30). YM, tells young woman that "if its hearts and flowers you're looking for, try to initiate some romance yourself. . . . If your boyfriend is like most guys, he should take the hint and start doing nice things for you. But don't expect him to change overnight; some guys can be really thickheaded about picking up clues" (Blanchard, 1994 p. 37). The implication is clearly that their behavior can be changed eventually. Other solutions, offered by Seventeen, 
include reassuring guys of their worth and changing guy behavior (e.g., dating other girls) through the sharing of feelings (Borchart, 1974; Schwartz, 1984b). Conversely, YM, warns girls that guys who don't want a "used tire" (i.e., non-virgins), should be dumped (Blanchard, 1994, p. 37). It should also be noted that the advice given by $\underline{Y M}$ in this latter situation also included one of the few references we found about AIDS: "He, as your new partner, has the right to know your sexual history -- what with AIDS and other sexually transmitted diseases" (Blanchard, 1994, p. 37). Significantly, the woman was not encouraged to press him for information about his sexual history. In fact, and in contrast to Strasburger's claim that print media are more informative about birth control, we found only 8 overt mentions about birth control, and 9 about sexually transmitted diseases or AIDS and all but two appeared in the 1994 issues of YM, Seventeen, Mademoiselle and Glamour.

Women as Sex Therapists. Not only must young women adapt themselves to male defined sexual expression, they must also teach him his own needs and how to satisfy them. While this theme did not appear overtly in the 1974 sample, it was foreshadowed in its grooming young women to communicate well with men, on their terms. By 1984, however, whether the magazines targeted younger or older teens, the sex therapist character theme was clear -- it's women's job to teach men how to be good lovers, and to adapt themselves to male desires and needs. The explicitness of the messages, especially those from 1994, reflect more graphic sexual content rather than sexual agency on the part of women. Overall, male pleasure orients and drives the advice.

On one level, teen magazines encourage young women to think of themselves and their needs; to be independent, assertive, selfassured and confident of their body image. Young women are told to move at their own pace and respect themselves by standing up to guys and avoiding male pressure to engage in activities that make them feel uncomfortable. Seventeen advises: "In terms of sexual activity, it's always possible to slow down, and anyone can choose to go from intercourse to kissing or anywhere in between. What you do -and don't do -- is entirely up to you" (Kent, 1994, p. 114). Magazines aimed at younger teens especially encourage them to refuse unwanted sexual moves even if they have been active in past. "Though you may 
have been sexually involved in the past, this doesn't mean that you are obligated to continue to be sexually active. . . . Let him know that it's not acceptable for him to pressure you. You said no, and you mean it" ("Ask Juli," 1994a, p. 6). Girls are also urged to "reconsider staying in a relationship" that's making them "unhappy" or where guys engage in unkind "macho" behavior (Schwartz, 1984b, p. 69).

However, once they have crossed the threshold of intercourse, the magazines implicitly and explicitly persuade girls to act as sex therapists in the male/female relationship. This is especially true in the 1984 and 1994 magazines directed toward older teens who are told sexual issues are their responsibility through articles and advice on how to deal with male sexual desires such as a menage 'a trois (Vernon, 1994, p. 78) or even anal sex (Lever \& Schwartz, 1994b, p. 69 ). The magazines also provide a guide for dealing with sexual problems such as waning sexual desire (Markowitz, 1994), and premature ejaculation or male impotency (Nelson, 1984). Young women are encouraged to help their "guys" through these problems by directly addressing the problem (Rosenbaum, 1984), or looking for "love boosts" to get them out of a dull routine (Volchok, 1984). The predominate focus, however, is not on the young woman's own sexual needs, or even how to train a man to please her or to enjoy sex more.

Women as Communication Teachers. Across the entire spectrum, from younger to older markets, teen magazines encouraged young women to teach men emotional intimacy through acting as communication teachers and therapists. The best example was an article in the April 1984 issue of Glamour. Entitled "Men and Intimacy: How to Get Your Man to Open Up" the article noted that men can't help themselves because "He's paralyzed by his fears -- of rejection, of dependence, and that he's not the man he ought to be. He needs a woman's help" (Naifeh \& Smith, p. 290). The article then provides "Five ways to help him open up" and "ten ways to get him talking." Younger teens are counseled by $\underline{\mathrm{YM}}$ to:

"Remember that boys are human, too. They're sensitive (some experts say more so than girls), they need comforting, and they have feelings, thoughts, worries, dreams, just as you do. Work hard to see this side of boys, and respond to it" (Rubis, 1984, p. 48). Rarely, however, are the young women encouraged to

Journal of Communication, Vol. 48, No. 4 (December 1998): pg. 59-78. DOI. This article is (c) Wiley and permission has been granted for this version to appear in e-Publications@Marquette. Wiley does not grant permission for this article to be further copied/distributed or hosted elsewhere without the express permission from Wiley. 
discuss issues of pregnancy, birth control, or AIDS with the guys; the one exception is found in YM (Blanchard, 1994).

In teen magazines a young woman's primary schema, goal, and responsibility is presented as developing a working heterosexual relationship. 'Teen advises: "If you want to understand a guy, it's important to look at his actions. That way you'll be better able to understand the language he's been taught--the language of action" ("Why Guys Do What They Do," 1994, p. 34). According to Glamour, she must

Teach a man -- by example and encouragement; learn to listen more closely to the sometimes muted and indirect ways he may express his feelings; and try to understand the value of nonverbal forms of communication. "There is a male and female code of expression," says one psychiatrist, "and you have to know how to translate feelings and ideas into each other's language. Since it's not very likely that a man will try to learn the female code of expression on his own, a woman's going to have to make the effort to teach him her language." (Naifeh \& Smith, 1984, p. 355)

In other words, she must, "in a sense, tutor the guy" by example ("Why Guys Do What They Do," 1994, p. 34). She can do this by "being open herself," "accepting his foibles," "not forcing the issue," and "seeing the problem from his side" (Naifeh \& Smith, 1984, pp. 354-355). That young women should put the guy and his problems first is best illustrated in the advice that: if she must complain, a "girl" should first "validate" her boyfriend's feelings. In the time honored tradition of wife meeting weary warrior husband, she must put her boyfriend's needs first and foremost.

\section{A Rhetorical Vision of Containment}

Teen magazines' columns, stories, and features on sex and heterosexual relationships present a simple, clear rhetorical vision: The sexual community belongs to men and women survive through containing themselves by adapting and subjugating themselves to male desires. This drama or fantasy is comprised of three types: setting, character and action. The setting for the sexual drama is 
everywhere and nowhere. The characters are heterosexual men and women; each with their own characteristics. In teen magazines, man is depicted as animal (unself- conscious) and woman is depicted as animal trainer. How demeaning that is given men's role in the creation of ethical, moral, philosophical, and religious systems. And how small a sop that is to women, to be given only private and no public power. This persona is not very different from the one projected in advertising and other media. Strasburger (1995) and Greenberg et al. (1997) found that while sexual content in television and music videos has increased in quantity and explicitness traditional depiction's of men as sexually powerful and aggressive and women as the sexually weak and submissive are pervasive. Cross culturally, Zoonen (1994) found that despite their extensive spiritual and intellectual training, geishas are perceived by western males, especially, as objects and providers of male sexual desires (p. 80). Similar negation of intellectual worth and promotion of erotic fantasies have been held about African women ( $p$. 82 ). In teen magazines, the fantasy action for young white women perpetuates the Victorian idea of woman as the keeper of the flame of male-defined culture. She becomes the keeper by developing a selfdenying, male-affirming persona shaped, influenced, and determined by the hegemonic sexuality of the drama.

The rhetorical community developed through the working out of this vision is impoverished, as well. By implication, the community of people bound together by this common vision is made up of young, white, heterosexually active men and women who have no fear of, or concerns about, AIDS, other sexually transmitted diseases, or pregnancy. Over time and magazine the characters within the community have not changed. The fantasy actions, however, have changed somewhat with younger girls assumed to be more openly and explicitly engaging in sexual relations with men and older teens doing the same (plus also serving as sexual therapists). Mademoiselle and Glamour were more explicit but the other magazines were not far behind. There are few virgins, no gay men or lesbian women, no men interested in learning how to love women, no women who think as highly of themselves as they do of men; just sexually experienced guys and girls. Whether young girls' real world experiences enable them adequately to critique these actions and the overwhelming sense that everyone else is "doing it" remains to be explored.

Journal of Communication, Vol. 48, No. 4 (December 1998): pg. 59-78. DOI. This article is @ Wiley and permission has been granted for this version to appear in e-Publications@Marquette. Wiley does not grant permission for this article to be further copied/distributed or hosted elsewhere without the express permission from Wiley. 
Other than brief mentions of masturbation in Seventeen (McCoy, 1984), lesbian dreams in Mademoiselle (Vernon, 1994), bisexual men who put their female partners at risk in Glamour (Lever \& Schwartz, 1994a), and one story in Mademoiselle about a woman trying to save a gay man from being gay (Scott, 1984) we found no representations of homosexuality or masturbation that indicate these could be appropriate expressions of sexuality. While there also was nothing which condemned these sexual expressions, their absence could be seen as very limiting or isolating by young women with these interests. The question, then becomes: while the male centered heterosexual focus of the magazines may be regrettable is it not also an accurate depiction of our culture? Are these magazines not realistic in their fantasy themes and the community that is developed? The answer is, predominately, yes but that does not make the presentation any less problematic. Certainly, the goal, presented in these magazines, of pleasing one's sexual partner is desirable but at what expense? While young girls in teen magazines are given agency to say no that agency is overwhelmed by the message that their prime goal should be to please men and not given offense.

Within this vision, young women are told they must lose weight, learn about sophisticated sexual techniques, apply make-up well, dress sexily, and engage in self-analysis when (not if) their real world does not fit with the world depicted. This serves the purposes of the magazines well, to sell advertising. Female deficiency is needed in order to maintain advertising sufficiency. Editorial content that promotes knowledge about issues such as AIDS, abortion, and pregnancy do not fit advertisers' profiles of deficient women (Steinem, 1990). As Sassy, and Ms., found out, magazines that put women first do not prosper with advertisers. They fit neither the vision nor the community.

Far from presenting a "modern" and "up-to-date" image of women, one that might enhance young women's sense of their own sexual worth, contemporary teenaged girls magazines sound the same themes sounded for years in women's magazines and home economics textbooks--how to successfully meet the needs and desires of men. A 1913 edition of Josephine Morris' book Household Science and Arts, for example, notes for young women attending the Kirksville, Missouri Normal Practice School the following: "But the mother or home maker

Journal of Communication, Vol. 48, No. 4 (December 1998): pg. 59-78. DOI. This article is (C) Wiley and permission has been granted for this version to appear in e-Publications@Marquette. Wiley does not grant permission for this article to be further copied/distributed or hosted elsewhere without the express permission from Wiley. 
is expected to be unfailingly pleasant, cheerful, and patient, and to smooth out all difficulties, no matter how worn or tired she may be" (pp. 221-222). Similarly, the 1960s Amy Vanderbelt Success Program for Women provided advice which began: "A man arrives at his own door with the day's atmosphere--good or bad--still clinging to him. A sensitive wife greets him warmly and waits to take her cue from him" (Fischer, 1964, p. 43).

In essence, the rhetorical vision presented in teen magazines, and these earlier quotes for successful female life, is one of containment, in which women fit themselves into a subordinate, maledefined sexual role. May (1988), notes that containment was the "overarching principle" that guided post World War II Americans in their personal and political lives. May adds that "much of [society's] anxiety focused on women, whose economic and sexual behavior seemed to have changed dramatically" (p. 93). Working women and women who expressed their own sexuality outside of the home were seen as socially deviant and dangerous to home and country (pp. 94100). Popular culture and social and psychological "experts" joined the band-wagon, encouraging women to stay at home and adhere to family values. If they were unhappy with this arrangement, they were encouraged to look to themselves for the source of their displeasure and to consult the many self-help books and magazines to available to reduce their discomfort (May, 1988; Simonds, 1992; Tavris, 1992; Wolf, 1991). As Simone de Beauvoir observed, "Once again women are being defined in terms of 'the other,' once again they are being made into the 'second sex.'" (De Beauvoir quoted in Schwartzer, 1984, p. 103). That view, as well as that of May, appears to still be true -- at least in teen magazines. The story of female sexuality they tell leaves little room for oppositional readings; little space for young women who might want to find out how to please themselves or teach men how to please them; who might desire discussion of sexually transmitted diseases, of sexual abstinence, of masturbation, or of same sex relationships.

In For Her Own Good, Ehrenreich and English noted that 19th century feminists such as Charlotte Perkins Gilman and Olive Schreiner realized, "[t]he problem in the middle to upper classes was that marriage had become a 'sexuo-economic relation' in which women performed sexual reproductive duties for financial support" (1978, p. 
95). The training manuals, or primers noted above, guided young women to accept a reduced situation in the early and mid-20th century. We argue a similar, but not identical guiding function is fulfilled by the containment rhetoric of teenage girls magazines. Brumberg (1997) points out that at least in the past, women could count on men taking care of them. "Although girls now mature sexually earlier than ever before, contemporary American society provides fewer social protections for them, a situation that leaves them unsupported in their development and extremely vulnerable to the excesses of popular culture and to pressure from peer groups" ( $p$. $x v i i)$. While earlier cultural training manuals promised economic stability, if not advancement, to women who fulfilled their character roles, modern teen magazines offer little to women in return for their sexual and relational involvement with men. Indeed, these magazines tell young women not to nag, not to push for commitment, but to simply wait for whatever men wish to give them.

Magazines marketed to young men, such as $\mathrm{GQ}$ and Esquire, offer a message that complements those given to young women. As Barbara Ehrenreich observed, "The masculine ideal of popular culture has long since ceased to be the man in the grey flannel suit, trudging dutifully between office and home. It has become the millionaire hoop star with a stable of interchangeable gal pals..."(Ehrenreich, 1996, p. 36). When stories of heterosexual relations are told in men's magazines, they are stories of sexual conquest or of surviving demanding women (Esquire, June 1995). Men's style magazines tell an emotionally arid, sexually predatory story of male sexuality, one which dovetails into the story of female sexuality told in teenage girls' magazines.

The combination of stories may well be a potent one, reinforcing the cultural assumption that young teen males are fine just as they are and that the world is both oriented to and dominated by men. If young people take these messages to heart, they will continue to enact a vision where men are the citizens of the world and women are citizens of the world of men. Ultimately showing little change in story dynamic from the primers of yesterday, little influence from the feminist movement or twenty-years of political conservatism, and virtually no influence from the presence of AIDS in American society, teen magazines present young women with a limited rhetorical vision of the 
NOT THE PUBLISHED VERSION; this is the author's final, peer-reviewed manuscript. The published version may be accessed by following the link in the citation at the bottom of the page.

world. This vision of women as sex objects, sex therapists and interpersonal communication teachers rather than friends, partners, lovers, and mothers, promotes the subordination self for others and encourages young women to become contained once more.

\section{References}

1. Ask Juli. (1994a, October). 'Teen, 38, 10

2. Ask Juli. (1994b, April). 'Teen, 6

3. Bales, R. F. (1970). Personality and interpersonal behavior. New York: Holt, Rinehart and Winston.

4. Barbasch, A. (1984, October). The Ghost of your first love. Glamour, 325327

5. Baudry, F. \& Wiener, A. (1974, April). A woman's choice: Pregnancy or abortion. Mademoiselle 34, 42.

6. Blanchard, K. (1994, October). His side. YM, 37

7. Borchart, D. (1974, October). Relating. Seventeen, 36, 38.

8. Bormann, E. G. (1972). Fantasy and rhetorical vision: The rhetorical criticism of social reality. Quarterly Journal of Speech, 68, 288-305.

9. Bormann, E .G. (1985a). Symbolic convergence theory: A communication formulation. Journal of Communication, 35 (4),128-138.

10. Bormann, E .G.(1985b). The force of fantasy: Restoring the American dream. Carbondale: Southern Illinois University Press.

11. Brumberg, J. J. (1997) The body project: An intimate history of American girls. New York: Random House.

12. Carmody, D. (1994, December 8). Peterson will restart Sassy with push for older readers. New York Times, p. D19.

13. Clifford, C. (1994, April). Dear Katie. $\underline{\text { YM}, ~} 37$

14. Dating dilemmas. (1994, April) 'Teen, 18.

Journal of Communication, Vol. 48, No. 4 (December 1998): pg. 59-78. DOI. This article is @ Wiley and permission has been granted for this version to appear in e-Publications@Marquette. Wiley does not grant permission for this article to be further copied/distributed or hosted elsewhere without the express permission from Wiley. 
NOT THE PUBLISHED VERSION; this is the author's final, peer-reviewed manuscript. The published version may be accessed by following the link in the citation at the bottom of the page.

15. Dear Jill. (1984, October). 'Teen, p. 24.

16. Defleur, M., \& Ball-Rokeach, S. (1982). Theories of mass communication. New York: Longman.

17. Duffy, M., \& Gotcher, M. J. (1996). Crucial advice on how to get the guy: The rhetorical vision of power and seduction in the teen magazine $\underline{Y M}$. Journal of Communication Inquiry, 20(1), 32-48.

18. Duke, L. (1995, August). From Seventeen to Sassy: Teen magazines and the construction of the 'model' girl. Paper presented at the annual conference of the Association for Education in Journalism and Mass Communication, Washington, D.C.

19. Duncan, S. (1994, October). Sex + Body. Seventeen, 100-101.

20. Durbin, K. (1974a, April). The intelligent woman's guide to sex. Mademoiselle, 94

21. Durbin, K. (1974b, October). The intelligent woman's guide to sex. Mademoiselle, 70

22. Durham, G. (1996). The taming of the shrew: Women's magazines and the regulation of desire. Journal of Communication Inquiry, 20(1),_1831.

23. Ehrenreich, B., \& English, D. (1978). For her own good. Garden City, NY: Anchor Press.

24. Ehrenreich, B. (1996, May 6). Whose gap is it anyway? Time, 147, p. 36.

25. Evans, E. D., Rutberg, J., Sather, C., \& Turner, C. (1991, September). Content analysis of contemporary teen magazines for adolescent females. Youth and Society, 23 (1),_99-120.

26. Ferguson, M. (1983). Forever feminine: Women's magazines and the cult of femininity. London: Heinemann.

27. Finders, M. J. (1997). Just girls: Hidden literacies and life in junior high. New York: Teachers College Press.

Journal of Communication, Vol. 48, No. 4 (December 1998): pg. 59-78. DOI. This article is @ Wiley and permission has been granted for this version to appear in e-Publications@Marquette. Wiley does not grant permission for this article to be further copied/distributed or hosted elsewhere without the express permission from Wiley. 
NOT THE PUBLISHED VERSION; this is the author's final, peer-reviewed manuscript. The published version may be accessed by following the link in the citation at the bottom of the page.

28. Fine, M. (1988). Sexuality, schooling, and adolescent females: The missing discourse of desire. Harvard Educational Review, 58 (1), 2853.

29. Fischer, N. (1964). How to help your husband get ahead. Garden City, NY: Doubleday.

30. Fisher, W. (1987). Human communication as narration: Toward a philosophy of reason, value, and action. Columbia, SC: University of South Carolina Press.

31. Frazer, E. (1987). Teenage girls reading Jackie. Media, Culture, and Society, 9, 407-425.

32. Fuller, B. (1994, April). Love crisis. YM, 28

33. Gilligan, C., Lyons, N. P. and Hanmer, T. J. (1990). Making connections: The relational worlds of adolescent girls at Emma Willard School. Cambridge: Harvard University Press.

34. Graeber, L. (1984, April). Teen pregnancy: "It couldn't happen to me." $\underline{\mathrm{YM}}, 46-48,76-77$.

35. Greenberg, B. S., Brown, J. D., and Buerkel-Rothfuss, N. L. (1997). Media, sex and the adolescent. Cresskill, NJ: Hampton Press.

36. Kellner, D. (1995). Cultural studies, multiculturalism and media culture. In G. Dines \& J. M. Humez (Eds.), Gender, race and class in media: A text-reader. (pp. 5-17). London: Sage.

37. Kellogg, M. A. (1984, October). How two teens faced Pregnancy: "I had an abortion"/ "I kept my baby"Seventeen, 144-146.

38. Kent, D. (1994, April). Sex Body. Seventeen, p.112-113.

39. Larsen, E. (1990, July). Censoring sex information: The story of 'Sassy.' Utne Reader, 40, 96-97.

40. Lee, S. (1994, October). Love Crisis. YM, 38

41. Lever, J. \& Schwartz, P. (1994a, April). Sex \& Health. Glamour, 76-78.

42. Lever, J. \& Schwartz, P. (1994b, October). Sex \& Health. Glamour, 69.

Journal of Communication, Vol. 48, No. 4 (December 1998): pg. 59-78. DOI. This article is @ Wiley and permission has been granted for this version to appear in e-Publications@Marquette. Wiley does not grant permission for this article to be further copied/distributed or hosted elsewhere without the express permission from Wiley. 
NOT THE PUBLISHED VERSION; this is the author's final, peer-reviewed manuscript. The published version may be accessed by following the link in the citation at the bottom of the page.

43. Markowitz, L. (1994, April). Cycles of Desire Glamour, 226-227, 281-283.

44. May, E. T. (1988). Homeward Bound: American families in the cold war era. New York: Basic Books.

45. McCracken, E. (1993). Decoding women's magazines: From Mademoiselle to Ms. Houndmills, England: Macmillan.

46. McCoy, K. (1984, October). Sex and your body. Seventeen, 12-14.

47. McRobbie, A. (1991). Feminism and youth culture: From Jackie to Just Seventeen . Boston: Unwin Hyman.

48. Moore, S., \& Rosenthal, D. (1993). Sexuality in adolescence. New York: Routledge.

49. Morris, J. (1913). Household science and arts. New York: American Book.

50. Naifeh, S.\& Smith, G. W. (1984, April). How to get your man to open up. Glamour, 290-293, 354-357, 363-365.

51. Nelson, P. (1984, October). Growing up the hard way. Mademoiselle, 156$157,254,256$.

52. Nguyen, M. (1994, April). Teen to Teen, 'Teen, 30.

53. Peirce, K. (1990). A feminist theoretical perspective on the socialization of teenage girls through 'Seventeen.' Sex Roles, 23 (9/10), 491-500.

54. Peirce, K. (1993). Socialization of teenage girls through teen-magazine fiction: The making of a new woman or an old lady? Sex Roles, 29 $(1 / 2), 59-68$.

55. Peirce, K. (1995). Socialization messages in Seventeen and 'Teen Magazines. In C. M. Lout (Ed.), Women and media: Content/careers/criticism. (pp. 79-86). Belmont, CA: Wadsworth.

56. Pool, G. (1990). Magazines in review. Wilson Library Bulletin, 95 (4), 131135.

57. Rosenbaum, M.B. (1984, October). Body and soul. Mademoiselle, 50.

Journal of Communication, Vol. 48, No. 4 (December 1998): pg. 59-78. DOI. This article is @ Wiley and permission has been granted for this version to appear in e-Publications@Marquette. Wiley does not grant permission for this article to be further copied/distributed or hosted elsewhere without the express permission from Wiley. 
NOT THE PUBLISHED VERSION; this is the author's final, peer-reviewed manuscript. The published version may be accessed by following the link in the citation at the bottom of the page.

58. Rubis, S. (1984, October). 10 ways to be popular with boys. $\underline{\text { YM, }} 46-48$, 76.

59. Schwartz, G. (1984a, April). Boy's-eye View. Seventeen, 104.

60. Schwartz, G. (1984b, October). Boy's-eye View. Seventeen, 68.

61. Schwartzer, A. (1984). After "The second sex": Conversations with Simone de Beauvoir. New York: Pantheon.

62. Scott, J. (1984, April). I loved a gay man. Mademoiselle, 272-279.

63. Silverman, D. (1993). Interpreting qualitative data: Methods for analysing talk, text and interaction. Thousand Oaks: Sage

64. Simonds, W. (1992). Women and self-help culture: Reading between the lines. New Brunswick, NJ: Rutgers University Press.

65. Soria, S. S. (1984a, April). Sexual involvement: The Experts answer your questions. 'Teen, 9-12, 100.

66. Soria, S. S. (1984b, October). Premature parenthood: Coping with the consequences. 'Teen, 10-11, 91--93.

67. Standard rate and data: Consumer magazine and agri-media source. (1995, January). U.S. Consumer Magazines. Willmette, IL: Standard Rate and Date Service.

68. Steinem, G. (1990, July/August). Sex, lies \& advertising. Ms. 18-28.

69. Steiner, L. (1995). Would the real women's magazine please stand up . . . for women. In C. M. Lout (Ed.), Women and media: Content/careers/criticism.(pp. 99-110). Belmont, CA: Wadsworth.

70. Strasburger, V. (1995). Adolescents and the media: Medical and psychological impact. housand Oaks: Sage.

71. Tavris, C. (1992). The mismeasure of woman. New York: Simon \& Schuster.

72. Teenage Research Unlimited. (1991). New York: Teenage Research Unlimited.

73. The Truth Behind the VD Scare. (1974, October). 'Teen, 26-30

Journal of Communication, Vol. 48, No. 4 (December 1998): pg. 59-78. DOI. This article is @ Wiley and permission has been granted for this version to appear in e-Publications@Marquette. Wiley does not grant permission for this article to be further copied/distributed or hosted elsewhere without the express permission from Wiley. 
74. Thompson, S. (1995). Going all the way: Teenage girls' tales of sex, romance and pregnancy. New York: Hill and Wang.

75. TV Turn-ons. (1994, October). YM, p. 78-83.

76. Vernon, B. (October, 1994). Sex. Mademoiselle, 78.

77. Volchok, S. M. (1994, April). Love Boosts: How to rev up a relationship that's slipped into the doldrums. Glamour 208-215.

78. Whoa! Stop boyfriend woes. (1994, April). 'Teen, 44-47.

79. Why guys do what they do .(1994, October). 'Teen, 32-34.

80. Wolf, N. (1991). The beauty myth: How images of beauty are used against women. New York: Anchor Books.

81. Wood, A. (1974, April). Relating. Seventeen 58, 62.

82. You, Your Parents and "His Body." (1974, October). 'Teen, 18-20.

83. Zoonen, L. van (1994). Feminist media studies. Thousand Oaks: Sage. 
NOT THE PUBLISHED VERSION; this is the author's final, peer-reviewed manuscript. The published version may be accessed by following the link in the citation at the bottom of the page.

\section{Author Note}

Ana C. Garner (Ph.D., University of Iowa, 1992) is assistant professor of journalism at Marquette University. Her interests include women and popular culture. Helen M. Sterk (Ph.D., University of Iowa, 1986) is associate professor of communication studies (now at the department of communication arts and sciences, Calvin College). Her interests include rhetorical criticism and women and popular culture. Shawn Adams (B.A., Loyola University, New Orleans, 1994) is a masters candidate at Marquette University. Her area of interest is rhetorical criticism. The study is supported in part by a grant from the College of Communication at Marquette University. The authors would like to thank Hanno Hardt and Karen Slattery for their help on earlier drafts and the anonymous reviewers whose detailed comments and suggestions strengthen the paper. An earlier version of this research was presented to the Organization for the Study of Communication, Language and Gender in Minneapolis, MN in 1995.

\section{About the Authors}

Ana Garner : $\quad$ Ph.D., University of Iowa, 1992. Assistant Professor, Department of Journalism, Marquette University, P.O. Box 1881 Milwaukee, WI 53201-1881.

Email: GarnerA@vms.csd.mu.edu

Phone: (414) 288-7383

Fax: (414) 288-3099

Helen M. Sterk : Ph.D., University of Iowa, 1986. Professor, Department of Communication, Arts and Sciences Calvin College, Grand Rapids, Michigan.

Shawn Adams : $\quad$ B.A., Loyola University - New Orleans, 1994. M.A. degree candidate, Department of Communication Studies, Marquette University.

Journal of Communication, Vol. 48, No. 4 (December 1998): pg. 59-78. DOI. This article is @ Wiley and permission has been granted for this version to appear in e-Publications@Marquette. Wiley does not grant permission for this article to be further copied/distributed or hosted elsewhere without the express permission from Wiley. 